\title{
KARAKTERISASI ELEKTROLIT POLIMER OPTIMUM KITOSAN/PVA+KOH
}

(Characterization of optimum Chitosan/PVA+KOH polymer electrolyte)

\author{
R.Putri ${ }^{1}$, A.Maddu ${ }^{2}$, Irzaman $^{2}$ \\ ${ }^{1}$ Departemen Fisika, Universitas Muhammadiyah Riau \\ ${ }^{2}$ Departemen Fisika, Institut Pertanian Bogor
}

\begin{abstract}
The blend-based polymer electrolyte comprising of chitosan and polyvinyl alcohol (PVA) as host polymers and potassium hydroxide $(\mathrm{KOH}) 35 \%$ wt as the complexing salt was studied. Polymer electrolyte were obtained by the casting technique. FTIR, XRD, SEM and EDX studies have been made to investigate the structural, complexation in film morphology of the polymer electrolyte.
\end{abstract}

Keywords : polymer electrolyte, FTIR, DSC, XRD, SEM, EDX

\section{PENDAHULUAN}

Pada penelitian dilakukan analisa spektroskopi FTIR, DSC, XRD, SEM, EDX pada elektrolit polimer Kitosan/PVA+KOH $35 \%$. FTIR merupakan salah satu jenis spektroskopi yang bersifat kualitatif. Penyinaran sampel dengan FTIR menyebabkan peristiwa transisi energi vibrasi molekul polimer. Sinyal hasil penangkapan detektor selanjutnya ditransformasikan dari bentuk sinyal biasa menjadi sinyal yang lebih kontinu dengan menggunakan transformasi fourier. Hasil analisis diharapkan menunjukkan sinyal yang khas

Analisa SEM digunakan untuk mengetahui morfologi permukaan elektrolit polimer. Perbesaran 100-1000x digunakan untuk menganalisa morfologi permukaan elektrolit polimer. EDX merupakan analisis yang terintegrasi dengan SEM dan digunakan untuk analisis unsur yang terdapat dalam elektrolit polimer. RD banyak digunakan untuk menentukan sifat sampel, identifikasi fasa, analisis kuantitatif dari fasa campuran dan ukuran partikel. Konduktivitas ionik polimer elektrolit secara kualitatif dapat dikaitkan dengan analisa
XRD. Dari analisa XRD dapat dilihat hubungan antara fasa elektrolit dengan konduktivitas ionik elektrolit polimer.

\section{METODOLOGI PENELITIAN}

Penelitian ini dilakukan di Laboratorium Biofisika Departemen Fisika IPB dan Balai Penelitian Pengembangan Hasil Hutan dari Februari sampai Juni 2009.

Bahan-bahan yang digunakan dalam penelitian ini diantaranya adalah kitosan, polivinil alkohol (PVA), aquades, asam asetat, dan $\mathrm{KOH}$. Alat yang digunakan dalam penelitian ini adalah neraca analitik, gelas piala, pipet tetes, pipet Mohr, gelas ukur Iwaki $10 \mathrm{ml}$ dan $100 \mathrm{ml}$, hot plate, cawan petri, hot plate stirrer, tissue, Bransonic 2510 dan furnace (tanur). Alat karakterisasi yang digunakan diantaranya adalah: LCR meter, Shimadzu X Ray

Diftraktometer, SEM Brucer $133 \mathrm{eV}$ dan Brucer FTIR.

Kitosan sebanyak 0,25 gram dilarutkan dalam $10 \mathrm{ml}$ asam asetat $1 \%$ dengan metode sonikasi selama 4 jam. Kemudian ditambahkan PVA sebanyak 0,25 gram. Proses pencampuran dilakukan dengan menggunakan hot plat stirrer pada 
temperatur 80 oC sampai larutan homogen.

Campuran kitosan-PVA yang telah homogen ditambahkan $\mathrm{KOH}$ dengan konsentrasi $35 \%$ wt. Campuran kitosan/PVA+KOH $35 \%$ wt didinginkan pada suhu ruang dan diukur konduktivitasnya dengan menggunakan LCR meter. Untuk karakterisasi dilakukan solution casting pada cawan petri. Untuk menghilangkan pelarut, dilakukan pengeringan dengan furnace pada temperatur $80 \quad$ oC selama 4 jam. Karakterisasi yang dilakukan yaitu FTIR, DSC, XRD, SEM, dan EDX.

\section{HASIL DAN PEMBAHASAN \\ FTIR (Fourier Transform Infrared)}

FTIR digunakan untuk menentukan jenis ikatan dan gugus fungsi pada molekul kompleks. Analisa ini banyak digunakan untuk melihat adanya kompleks garampolimer dalam elektrolit polimer. FTIR merupakan instrumen yang efisien untuk mempelajari perubahan struktur lokal yang terdapat pada polimer. Spektra inframerah material bervariasi bergantung pada komposisi dan sangat memungkinkan untuk mengetahui adanya kompleks elektrolit polimer dan interaksi antar komponen penyusunnya [1].

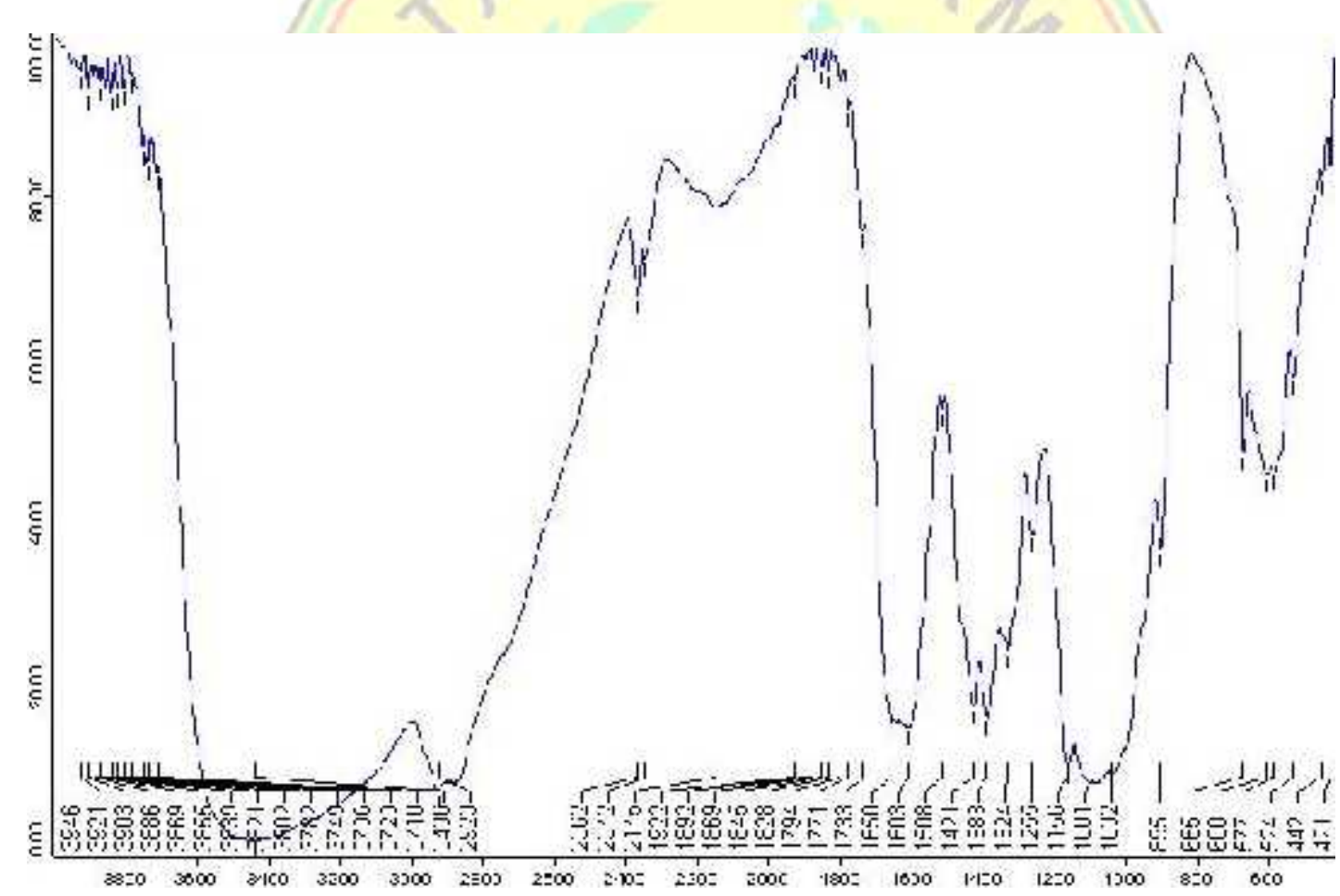

Gambar 1 Spektrum FTIR Kitosan

Spektrum gugus fungsi FTIR untuk kitosan yang digunakan pada penelitian ini dapat dilihat pada Gambar 1. Spektrum FTIR menunjukkan adanya uluran $\mathrm{NH}_{2}$ pada bilangan gelombang $3438 \mathrm{~cm}^{-1}$. Vibrasi $\mathrm{CH}_{3}$ terdapat pada bilangan gelombang 2923 dan $1383 \mathrm{~cm}^{-1}$. Terdapat ikatan $-\mathrm{S}-\mathrm{C} \equiv \mathrm{N}$ pada bilangan gelombang $2145 \mathrm{~cm}^{-1}$ dengan kekuatan sedang. Gugus fungsi $\mathrm{C}=\mathrm{O}$ muncul pada bilangan gelombang 1869, 1845,1794,1771, dan $1733 \mathrm{~cm}^{-1}$. Ikatan C=O yang lemah terdapat pada bilang gelombang 1869 dan1845 $\mathrm{cm}^{-1}$, ikatan $\mathrm{C}=\mathrm{O}$ dengan lima cincin pada bilangan gelombang 1794 dan $1771 \mathrm{~cm}^{-1}$, dan ikatan $\mathrm{C}=\mathrm{O}$ aldehid alifatik pada bilangan gelombang $1733 \mathrm{~cm}^{-1}$. 
Pada bilangan gelombang 1650 dan 1508 $\mathrm{cm}^{-1}$ masing-masing terdapat uluran $\mathrm{C}=\mathrm{C}$ dan $\mathrm{NO}_{2}$. Gugus fungsi $\mathrm{R}-\mathrm{CH}_{2}-(\mathrm{C} \equiv \mathrm{N})$ muncul pada bilangan gelombang $1421 \mathrm{~cm}^{-1}$ dan ikatan yang terbentuk lebih besar dari deformasi hidrokarbon. Amina tersubtitusi muncul pada bilangan gelombang $1324 \mathrm{~cm}^{-1}$ sedangkan ikatan O-C-O ansimetrik muncul pada $1255 \mathrm{~cm}^{-1}$. Uluran C-O terdeteksi pada bilangan gelombang $1080 \mathrm{~cm}^{-1}$ dan eter aromatik $\mathrm{O}-\mathrm{CH}_{2}$ terdeteksi pada $1032 \mathrm{~cm}^{-1}$. Kibasan $\mathrm{CH}_{2}$ dan $\mathrm{C}-\mathrm{H}$ muncul pada bilangan gelombang berturut-turut 895 dan $665 \mathrm{~cm}^{-1}$.

\begin{tabular}{cccr}
\multicolumn{2}{c}{ Spektrum } & FTIR & campuran \\
kitosan/PVA pada & Gambar 2 & (a)
\end{tabular} memperlihatkan puncak serapan inframerah yang lebih sederhana dibandingkan dengan puncak serapan kitosan. Hampir semua puncak serapan kitosan tidak muncul dalam campuran kitosan /PVA kecuali gugus fungsi $\mathrm{C}=\mathrm{O}$. Spektrum FTIR kitosan/PVA memperlihatkan adanya uluran gugus karbonat $\mathrm{C}=\mathrm{O}$ (dengan lima cincin) pada bilangan gelombang $1812,71 \mathrm{~cm}^{-1}$. Puncak tersebut sebelumnya muncul pada bilangan gelombang $1794 \mathrm{~cm}^{-1}$. Puncak pada bilangan gelombang 3347,99 $\mathrm{cm}^{-1}$ menunjukkan adanya gugus fungsi $\mathrm{NH}(\alpha$ amido acids) yang sebelumnya tidak muncul pada serapan inframerah kitosan.

Pada Gambar 2(b), spektrum FTIR kitosan/PVA+KOH menunjukkan adanya uluran NH dengan ikatan yang lemah pada panjang gelombang $3427,89 \mathrm{~cm}^{-1}$. Uluran $\mathrm{C}=\mathrm{N}$ pada bilangan gelombang $1637,03 \mathrm{~cm}^{-}$ 1. Dan uluran $\mathrm{N}=\mathrm{N}$ (ozo aromatis) pada panjang gelombang 1413,52 $\mathrm{cm}^{-1}$. Dan kibasan $\equiv \mathrm{C}-\mathrm{H}$ (mono substituted acetylenes) yang sangat kuat dan lebar pada panjang gelombang $658,88 \mathrm{~cm}^{-1}$. Gugus funggsi kitosan tidak muncul sama sekali pada elektrolit polimer kitosan/PVA+KOH. Namun gugus fungsi NH pada kitosan/PVA masih muncul setelah ditambahkan garam. Dari Gambar 5 dapat dilihat bahwa banyak puncak yang tidak muncul dan ada puncak baru yang ditemukan. Hal ini mengindikasikan bahwa telah terbentuk kompleks elektrolit polimer kitosan/PVA+KOH.

\section{Analisa SEM (Scanning Electron Microscope)}

Morfologi elektrolit polimer dapat dilihat dengan menggunakan SEM. Ciri-ciri morfologi seperti kehomogenan elektrolit polimer dan efek penambahan garam (salting effect) dapat ditentukan dari hasil foto SEM. Analisa SEM telah dilakukan pada sampel elektrolit polimer Kitosan/PVA dengan penambahan $\mathrm{KOH} 35 \%$. Dari foto SEM (Gambar 3a) dapat dilihat bahwa elektrolit polimer yang dihasilkan berupa elektrolit polimer dengan fasa amorf. Fasa amorf pada elektrolit polimer dapat meningkatkan konduktivitas ionik elektrolit polimer tersebut. Pencampuran kitosan dan PVA masih belum homogen. Hal ini dapat dilihat masih adanya penggumpalan. Namun morfologi yang dihasilkan tidak jauh berbeda dengan apa yang telah dilakukan oleh Mohamad AA dan Arof K (Gambar 3b) [2]. 


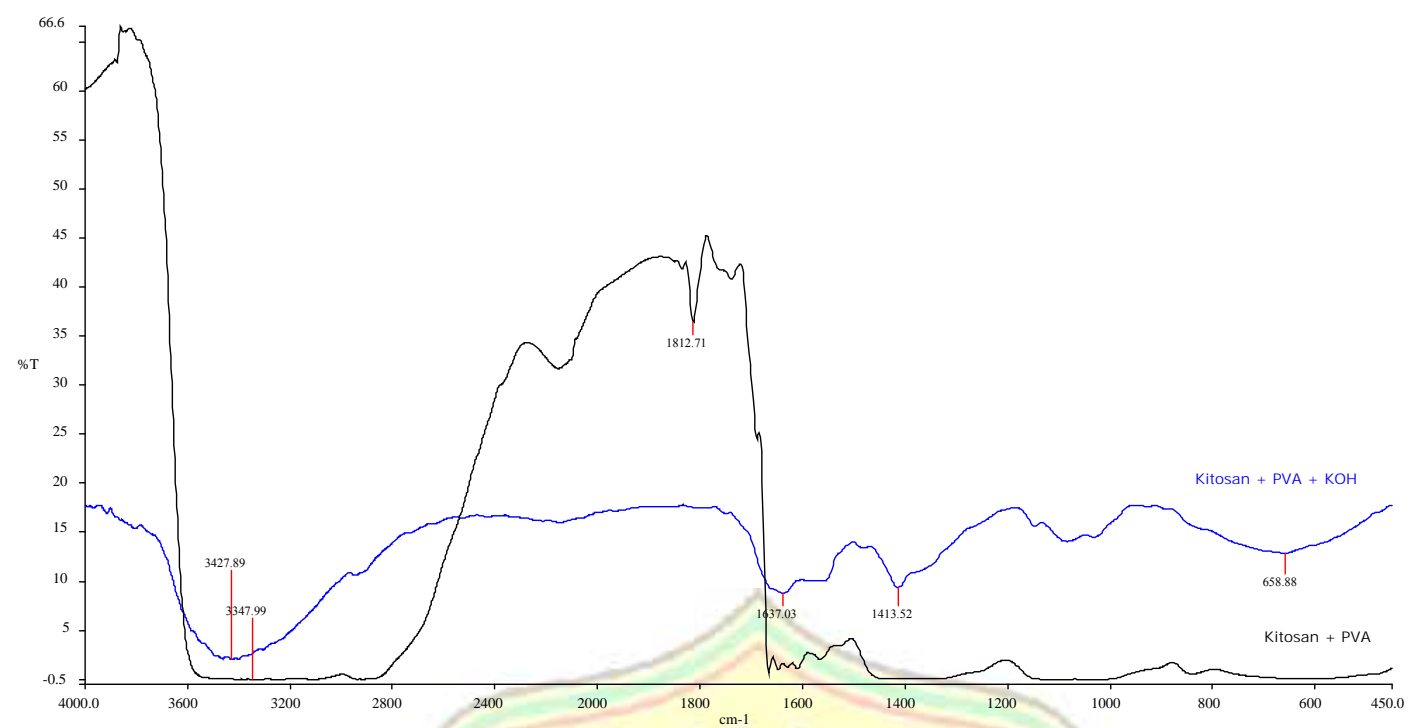

Gambar 2 Spektrum FTIR (a) Kitosan/PVA (b) Kitosan/PVA+KOH $35 \%$

Pada Gambar 3 (a) dapat dilihat adanya fase kristal yang terbentuk pada elektrolit polimer kitosan/PVA+KOH. Fasa kristal yang muncul pada Gambar 3 (a) merupakan fasa kristal dari PVA. Adanya proses pengkristalan ini disebabkan oleh proses pemanasan elektrolit polimer untuk menguapkan pelarutnya. Pemanasan ini sedikit berpengaruh pada pengkristalan PVA.

Pada Gambar 4a dan 4c dapat dilihat foto permukaan elektrolit polimer dengan kondisi tidak dipanaskan. Elektrolit polimer tersebut berada dalam fasa amorf yang terikat satu sama lain. Sedangkan pada Gambar $4 \mathrm{~b}$ dan $4 \mathrm{~d}$ dapat dilihat foto permukaan elektrolit polimer yang dipanaskan pada suhu $100{ }^{0} \mathrm{C}$ selama 1 jam. Dari gambar SEM tersebut dapat dilihat adanya perubahan permukaan elektrolit polimer. Elektrolit polimer yang dipanaskan cendrung memiliki permukaan lebih halus karena telah meleburnya PVA. PVA melebur pada suhu sekitar $85{ }^{\circ} \mathrm{C}$. Selain itu dapat dilihat adanya pengkristalan kembali $\mathrm{KOH}$ dalam sampel elektrolit polimer. Hal ini menyebabkan menurunnya konduktivitas ionik elektrolit polimer [1,3].

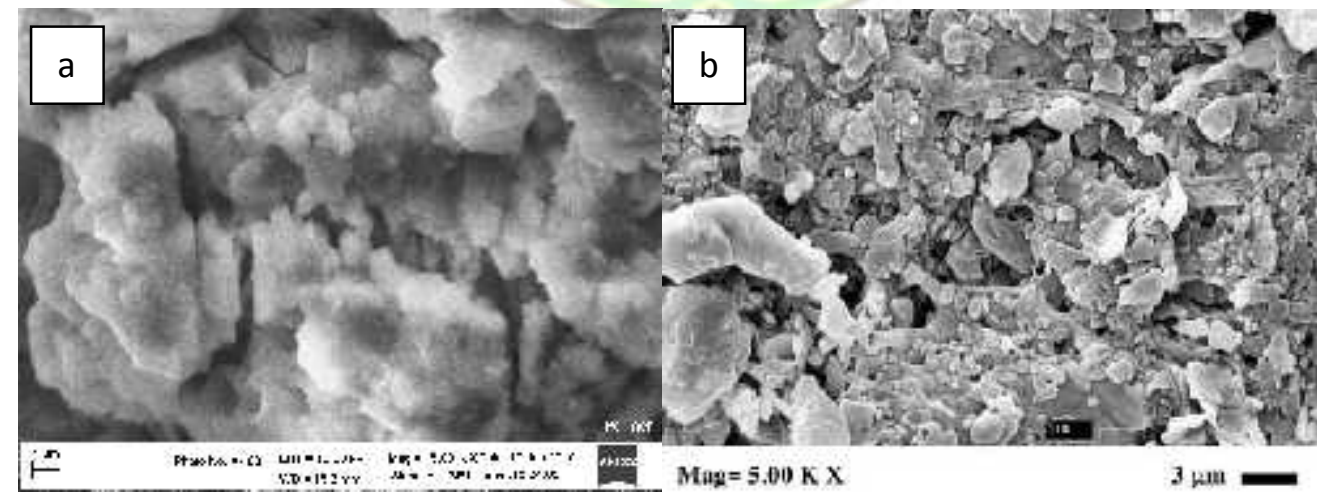

Gambar 3 Hasil SEM (a) Kitosan/PVA+KOH 35\% dan (b) PVA+KOH $40 \%$ 


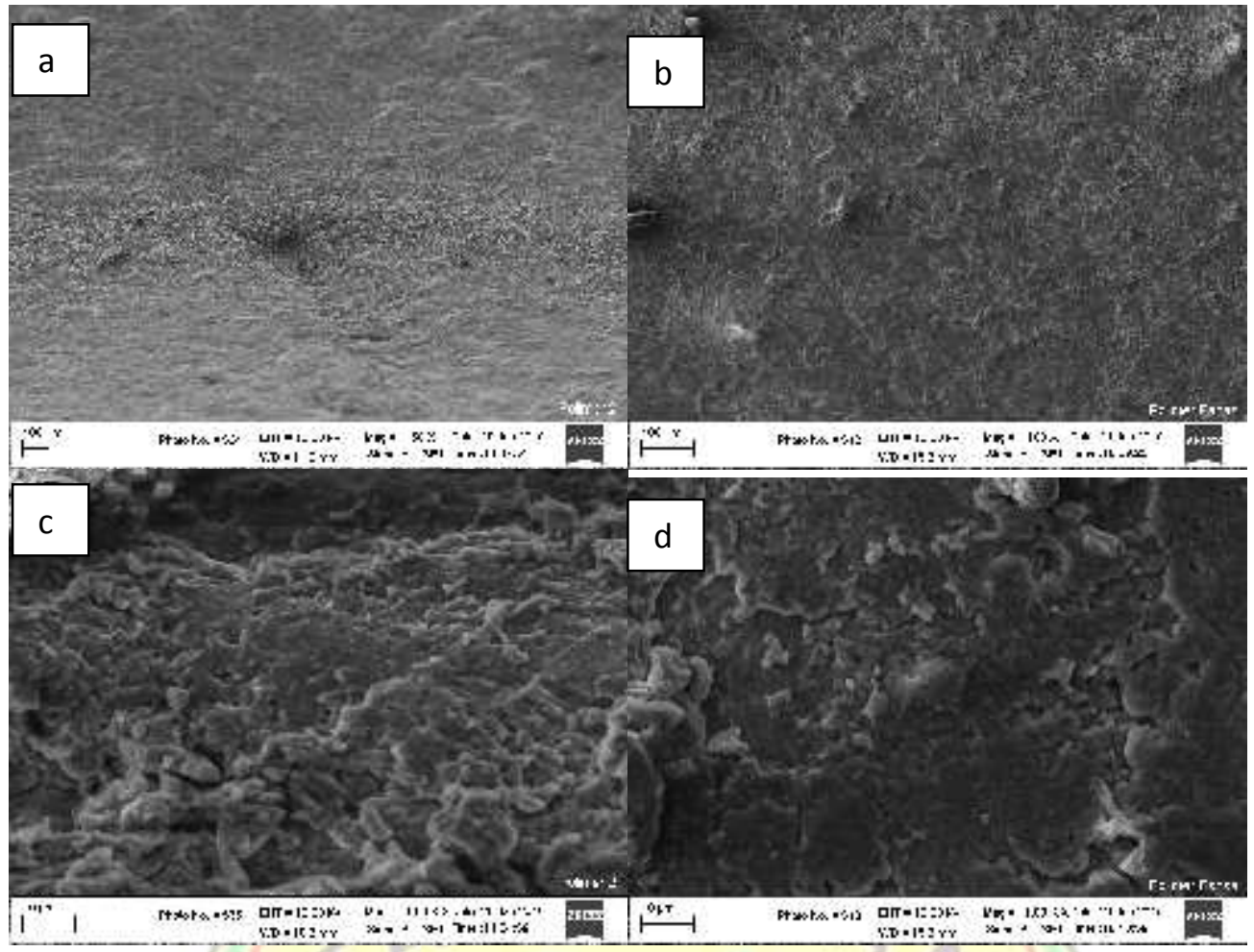

\section{Gambar 4 SEM Kitosan/PVA+KOH $35 \%$ (Pemanasan $100{ }^{\circ} \mathrm{C}$ )}

\section{XRD (X-Ray Diffraction)}

XRD banyak digunakan untuk menentukan sifat sampel, identifikasi fasa, analisis kuantitatif dari fasa campuran dan ukuran partikel. Konduktivitas ionik polimer elektrolit secara kualitatif dapat ditentukan dengan analisa XRD. Pola XRD Kitosan/PVA+KOH $35 \%$ tanpa perlakuan panas dapat dilihat pada Gambar 5 .

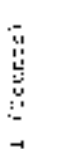

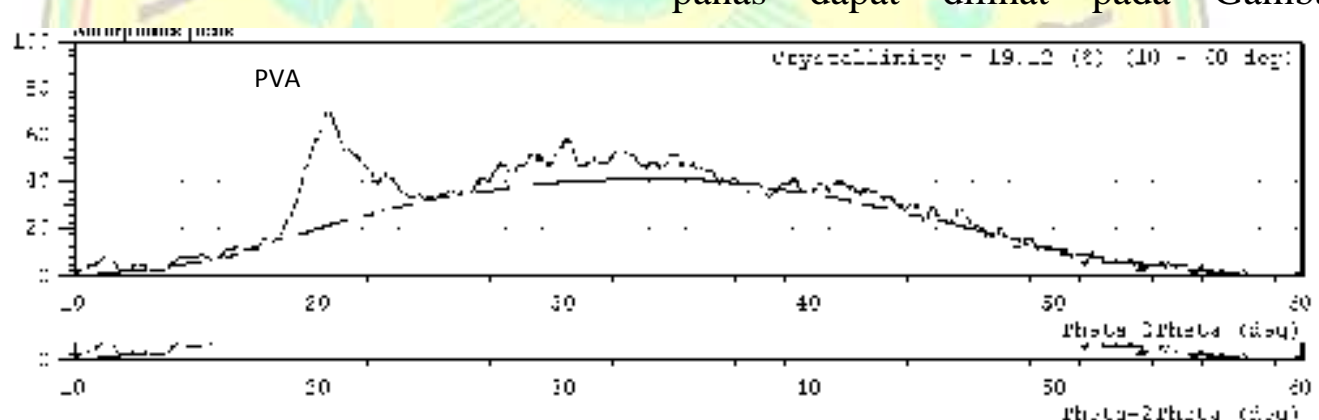

Gambar 5 XRD Kitosan/PVA+KOH $\left(25^{\circ} \mathrm{C}\right)$

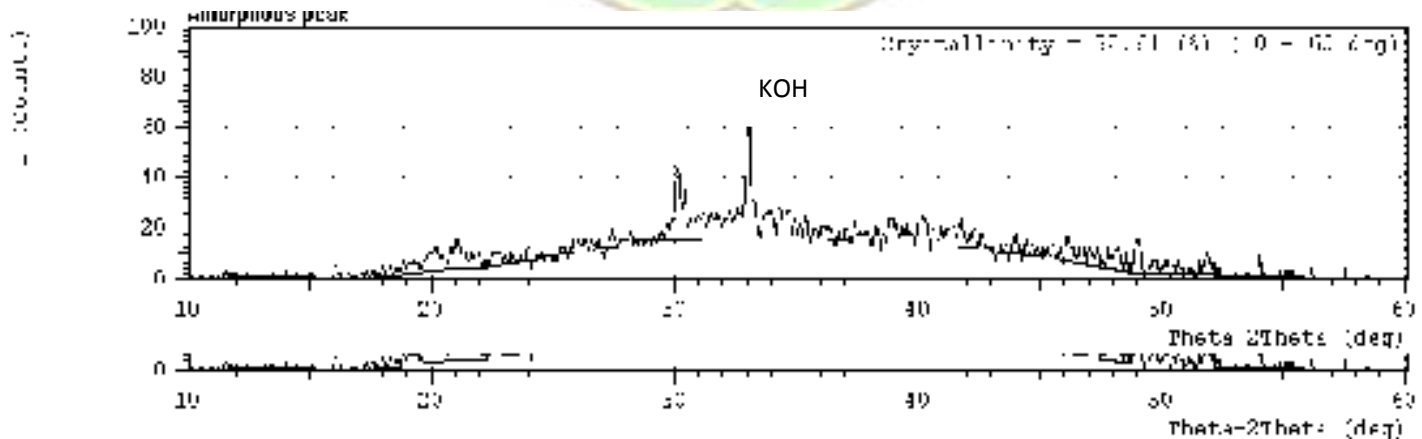

Gambar 6 XRD Kitosan/PVA+KOH $\left(100{ }^{\circ} \mathrm{C}\right)$ 
Dari hasil XRD, secara umum sampel yang terbentuk berupa elektrolit polimer dengan fasa amorf. Pada Gambar 5 dapat dilihat adanya puncak PVA yang muncul pada sudut $2 \theta=20,355^{\circ}$. Ini menjelaskan bahwa masih adanya PVA dalam bentuk kristal yang terdapat dalam elektrolit polimer [4]. Elektrolit polimer akan memiliki konduktivitas ionik tinggi jika fasa elektrolit polimer berada dalam fasa amorf. Persentase kristalinitas elektrolit polimer yang terbentuk sekitar 19,12\%. Penyumbang kristalinitas dalam elektrolit polimer ini adalah dari fasa kristal PVA. Puncak KOH tidak muncul pada pada hasil XRD elektrolit polimer.

Pada Gambar 6 dapat dilihat hasil XRD Kitosan/PVA+KOH $35 \%$ yang dipanaskan pada suhu $100{ }^{\circ} \mathrm{C}$ selama 1 jam. Pada gambar dapat dilihat adanya puncak $\mathrm{KOH}$ yang muncul sementara puncak PVA tidak terlihat dalam fasa kristal. Pada sampel yang dipanaskan dapat dilihat adanya pengkristalan ulang $\mathrm{KOH}$. Hal ini menyebabkan elektrolit polimer bersifat lebih kristalin sehingga dapat menurunkan konduktivitas ioniknya. Semakin kristalin suatu elektrolit polimer maka konduktivitas ioniknya akan semakin menurun. Puncak yang muncul pada sampel yang dipanaskan terdapat pada (20) $33.0435^{\circ}$ dengan derajat kristalinitas $32,61 \%$. Puncak maksimum yang muncul merupakan puncak $\mathrm{KOH}$. Persentase kristalinitas tersebut lebih besar $13,49 \%$ dari elektrolit polimer yang tidak dipanaskan. Pada penelitian sebelumnya yang dilakukan oleh Mohamad AA dan Arof $\mathrm{K}$, elektrolit polimer $\mathrm{PVA}+\mathrm{KOH}$ dengan pemanasan $\quad 100 \quad{ }^{\circ} \mathrm{C}$ memperlihatkan munculnya dua puncak yaitu PVA dan
$\mathrm{KOH}$. Hal ini menyebabkan kekristalin elektrolit polimer semakin meningkat karena kontribusi kekristalan disumbangkan oleh dua komponen dalam elektrolit polimer tersebut [5]. Ketika dilakukan pencampuran PVA dan kitosan, hanya PVA yang memberi kontribusi besar pada derajat kristalinitas elektrolit polimer.

\section{EDX (Energy Dispersive X-Ray Spectroscopy)}

Analisis EDX (Energy Dispersive $X$ Ray Spectroscopy) merupakan suatu teknik yang digunakan untuk mengidentifikasi komposisi unsur suatu sampel atau daerah disekitarnya. Sistem analisis EDX bekerja sebagai suatu bentuk terintegrasi dari Scanning Electron Microscope (SEM). Keluaran dari analisis EDX adalah berupa suatu spektrum EDX. Masing-masing puncak pada spektrum EDX adalah unik untuk setiap atom dan sangat sesuai untuk unsur tunggal [6]. Puncak yang lebih tinggi pada spektrum menunjukkan semakin banyaknya unsur tersebut dalam sampel. Hasil EDX kitosan/PVA+KOH 35\% memperlihatkan bahwa karbon merupakan unsur yang paling dominan pada elektrolit polimer yaitu sekitar 32,33\% wt. Persentase kalium yang terdapat dalam elektrolit polimer hanya sekitar $28,24 \%$. Secara umum mapping unsur dalam elektrolit polimer dapat dilihat pada Gambar 7. Pada Gambar 8 dapat dilihat penyebaran atom $\mathrm{K}^{+}$dalam elektrolit polimer. Tampak pada gambar bahwa penyebaran atom $\mathrm{K}^{+}$tidak terdistribusi merata pada sampel cuplikan. Dari gambar dapat dihitung kerapatan atom $\mathrm{K}^{+}$dalam elektrolit polimer yaitu sekitar 79 atom $\mathrm{cm}^{-2}$. 


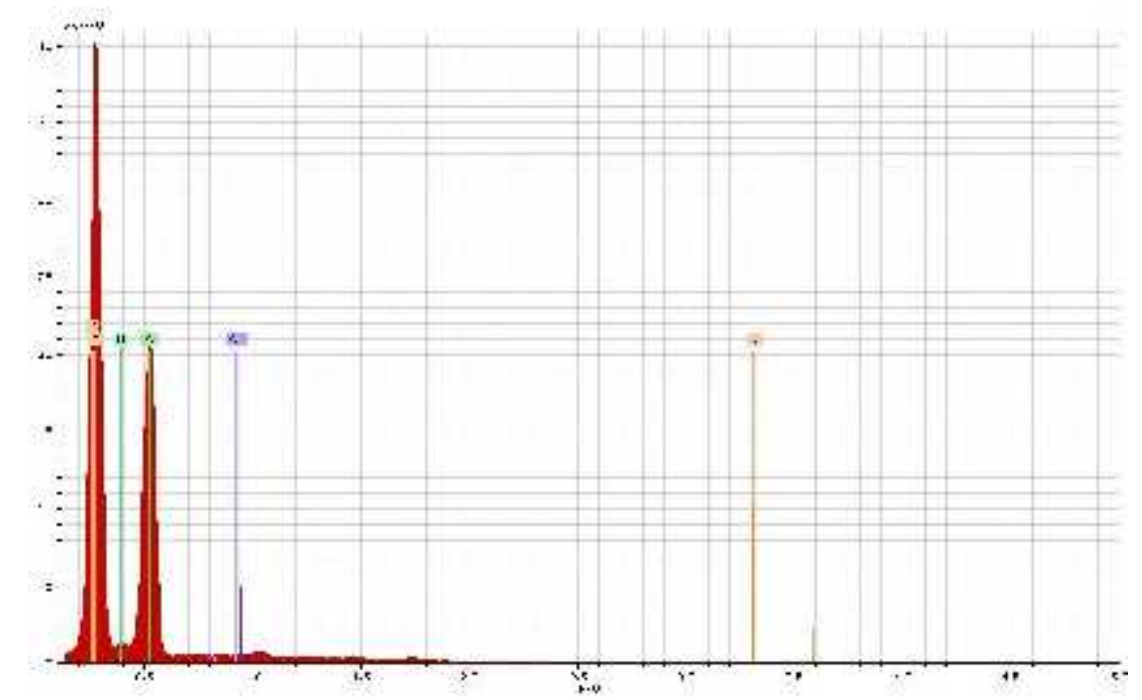

Gambar 7 Spektrum EDX Kitosan/PVA+KOH

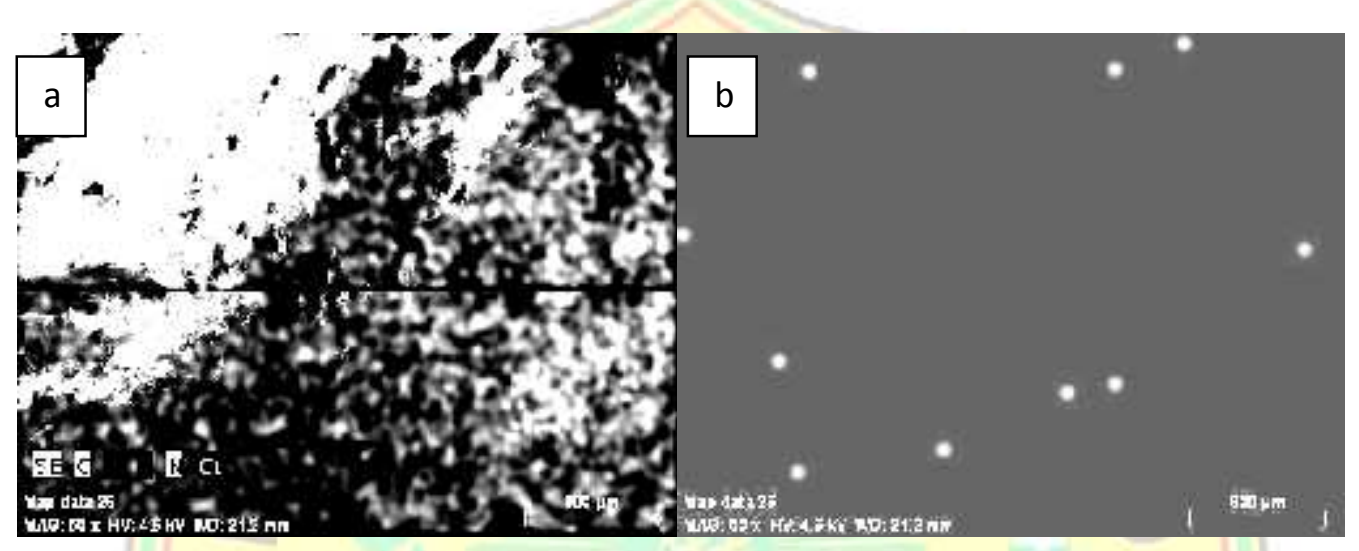

\section{Gambar 8 Mapping (a) Kitosan/PVA+KOH (b) KOH}

\section{KESIMPULAN}

Pada penelitian ini telah dilakukan karakterisasi elektrolit polimer kitosan/PVA+KOH dengan komposisi optimum $\mathrm{KOH} \quad 35 \%$ wt. Hasil FTIR menunjukkan banyak puncak yang tidak muncul dan adanya puncak baru pada elektrolit polimer. Hal ini mengindikasikan terbentuknya senyawa kompleks elektrolit polimer. Hasil SEM dan XRD menunjukkan adanya peningkatan kristalinitas elektrolit polimer akibat perlakuan panas. Sesuai dengan teori, konduktivitas menurun dengan semakin meningkatnya persentase kristalinistas. Analisa EDX kitosan/PVA+KOH $35 \%$ memperlihatkan bahwa kalium yang terdapat dalam elektrolit polimer sekitar 28,24\%. Foto EDX juga memperlihatkan bahwa penyebaran kalium masih belum merata di dalam sampel.

\section{DAFTAR PUSTAKA}

[1] Mohamad AA, Arof AK. Effect of storage time on the properties of $\mathrm{PVA}-\mathrm{KOH}$ alkalinesolid polymer electrolyte system. Ionics 2006;12: 57-61

[2] Rajendran S, Babu RS, Renuka Devi $\mathrm{K}$. Ionic conduction behavior in PVC-PEG blend polymer electrolytes upon the addition of TiO2. Ionics 2008; DOI 10.1007/s11581-008-0222-3 
[3] Jing Fu, Jinli Qiao, Xizhao Wang, Jianxin Ma, Tatsuhiro Okada. Alkali doped poly(vinyl alcohol) for potential fuel cell applications.

Synthetic Metals 2010; 160: 193-199

[4] Mohamad AA, Arof AK. Effect of storage time on the properties of $\mathrm{PVA-KOH}$ alkalinesolid polymer electrolyte system. Ionics 2006;12: 57-61
[5] Aisyah IN. Pembengkakan Hidrogel Kitosan-Polivinil Alkohol [skripsi]. Bogor: Fakultas Matematika dan Ilmu Pengetahuan Alam, Institut Pertanian Bogor; 2005

[6] Wan Y, Creber KAM, Peppley B, Bui VT. Synthesis, characterization and ionic conductive properties of phosphorylated chitosan membranes. Macromol. Chem. Phys 2003; 204: 850-858. 